\title{
Anti-inflammatories and analgesics in paediatric dentistry
}

\author{
Irina Lupse ${ }^{1}$, Alexandrina Muntean', Ioana-Andreea Chis ${ }^{1}$, Anca-Ioana Daniliuc ${ }^{1}$, \\ Mircea Ghergie ${ }^{2}$ \\ ${ }^{1}$ Department of Paediatric Dentistry, "Iuliu Hatieganu" University of Medicine and Pharmacy, \\ Cluj Napoca, Romania \\ ${ }^{2}$ Department of Orthodontics and Dentofacial Orthopedics, \\ "Iuliu Hatieganu" University of Medicine and Pharmacy, Cluj Napoca, Romania
}

\begin{abstract}
Analgesics are used to reduce pain, which is the main symptom experienced in dental inflammatory pathologies. Painkillers are among the most used drugs in dentistry, along with anti-inflammatories and antibiotics. A lack of knowledge regarding well-defined prescription protocols has been observed. The aim of this study was to revise and update the prescription of anti-inflammatories and analgesics according to the latest guidelines.

We performed electronic research of selected databases: PubMed, Google Scholar, AAPD, from 2010-2020, in order to identify the most frequent anti-inflammatories and analgesics used in paediatric dentistry.

Approximately $25 \%$ of all adverse drug reactions are the consequences of treatments with anti-inflammatory drugs. This paper focuses on both the correct and wrong prescription of medication in paediatric dentistry, as well as on the short and long-term side-effects of this prescription.
\end{abstract}

Keywords: anti-inflamatories, analgesics, pediatric dentistry, pedodontics, medication

\section{BACKGROUND AND AIMS}

The incidence of inflammatory pathologies has increased significantly over the past years, all over the world. The most simple inflammatory processes, up to the most complex diseases that affect multiple systems of the body, are treated, both in adults and children, with anti-inflammatory drugs [1].

Anti-inflammatory drugs are used to either prevent the inflammation, or to reduce it [2]. These synthetic drugs exert their effects through hormonal action, inhibiting the secretion of inflammatory enzymes, proteins and other factors involved in the inflammatory process. They can also promote the anti-inflammatory immune response. Depending on the presence or absence of steroids in their composition, anti-inflammatory drugs can be steroidal or non-steroidal [1].

Steroidal anti-inflammatory drugs were first synthesized to treat inflammatory processes. Their action is extremely strong and fast, the main mechanisms being: anti-inflammatory action (by inhibiting prostaglandin and LT synthesis, inhibiting cytokine production, decreasing the polymorphonuclear response) and immunosuppressive action, by decreasing the number of monocytes and lymphocytes [1].

In the past few years, there was an attempt to limit the use of steroidal anti-inflammatory drugs, due to important side effects such as: a weakened immune system, weight gain, hormonal disorders, muscle aches, nausea, vomiting, abdominal cramps and dilated pupils [1].

Nonsteroidal anti-inflammatory drugs are among the most widely used drugs worldwide to treat fever, pain, and inflammatory processes in both adults and children [6]. Based on their ability to inhibit the action of the enzymes responsible for inflammatory processes (COX1 and COX2), nonsteroidal anti-inflammatory drugs can be divided 
into 2 major groups: selective and non-selective [7]. A more detailed classification separates nonsteroidal anti-inflammatory drugs into: non-selective irreversible COX inhibitors; non-selective reversible COX inhibitors; preferential COX 2 inhibitors (meloxicam, etodolac, nabumetone); selective COX 2 inhibitors (celecoxib, etoricoxib, rofecoxib, valdecoxib); COX 3 inhibitor (PCM) [1]. Non-steroidal anti-inflammatory drugs can be also classified according to their chemical composition:

- salicylic acid derivatives: aspirin, diflunisal;

- propionic acid derivatives: ibuprofen, ketoprofen;

- phenylacetic acid derivatives: diclofenac;

- derivatives of carbocyclic and heterocyclic acetic acids: indomethacin, sulindac;

- pyrazolones;

- oxicams: piroxicam;

- fenamic acid derivatives: flufenamic acid, mefenamic acid;

- selective blockers: meloxicam, nimesulide;

- specific blockers: celecoxib [1].

Analgesics are used to reduce pain, which is the main symptom experienced in inflammatory pathologies [8]. Acetaminophen is a non-opioid analgesic known as Paracetamol, which has antipyretic properties [2].

Non-steroidal anti-inflammatory drugs are the most commonly prescribed drugs worldwide, for both adults and children [6]. More than 30 million people are using prescribed non-steroidal anti-inflammatory drugs daily [9]. Their widespread use is due to both anti-inflammatory and antipyretic effects [6].

\section{METHODS}

The sites accessed for this article were represented by PubMed, Google Scholar, AAPD. We've searched for articles such as: review, clinical protocols, cross-sectional studies, clinical studies, laboratory studies. Other criteria: articles were searched in English and published / revised in the last 10 years (2010-2020).

The keywords used to search the articles were: anti-inflammatory drugs, medication in pediatrics, drugs used in inflammation, steroidal anti-inflammatory drugs, non-steroidal anti-inflammatory drugs, NSAIDs in pediatrics, pain, paracetamol.
Out of a total of 98 articles found, 20 met the criteria of our chosen topic. The other studies were rejected because they lacked in relevance and/or specificity regarding this theme.

\section{INDICATIONS AND CONTRAINDICATIONS}

Painkillers are among the most used drugs in dentistry, along with antibiotics. Paracetamol is currently the analgesic of choice worldwide; however, it is marketed in such way that it is not recommended to use it for more than 3 days without consulting a specialist, despite being used in chronic diseases as well. Nevertheless, it is still recommended as a first-line treatment in countries such as the United Kingdom [10].

The selection of the right analgesic is recommended to be tailored to the patient and the specific dental /surgical procedure, taking into consideration a number of factors, such as the complexity and duration of the procedure, psychological factors, and the patient's medical history. Therefore, besides the complexity of the performed medical act, various pathologies such as liver diseases, kidney diseases, haematological disorders, are important factors when we are choosing the proper analgesic (table 1) [11].

TABLE 1. Form of presentation of Ibuprofen and Paracetamol in paediatric dentistry

\begin{tabular}{|l|l|l|}
\hline Author & The Medicine & Form of presentation \\
\hline $\begin{array}{l}\text { Maghiar I (2011), } \\
\text { AAPD (2019) }\end{array}$ & Ibuprofen & $\begin{array}{l}\text { suspension, tablets, } \\
\text { injectable form }[2,5,8]\end{array}$ \\
\hline $\begin{array}{l}\text { Maghiar I (2011), } \\
\text { AAPD (2019) }\end{array}$ & Acetaminophen & $\begin{array}{l}\text { suspension, tablets, } \\
\text { tablets with oral } \\
\text { disintegration, } \\
\text { pills, suppositories, } \\
\text { injectable form, limited } \\
\text { to 325 mg per unit dose } \\
\text { due to hepatotoxicity } \\
\end{array}$ \\
& & {$[2,5,8]$} \\
\hline
\end{tabular}

The pain management plan is recommended to take into account the patient's previous experiences with medical acts, post-operative treatment, medication allergies and intolerances, cognitive status, preferences for treatment and treatment goals (table 2) [11].

In a study published in 2019, Monisha et al. conclude that dental practitioners are aware that medications should be prescribed depending on the patient's clinical condition. Even so, prescriptions are filled out based on the systemic compli- 
TABLE 2. Dosage of Ibuprofen and Paracetamol in paediatric dentistry

\begin{tabular}{|c|c|c|c|c|}
\hline Author & The Medicine & Children $<12$ years & $\begin{array}{l}\text { Children }>12 \text { years } \\
\text { and young adults }\end{array}$ & $\begin{array}{c}\text { Maximum } \\
\text { recommended dose }\end{array}$ \\
\hline $\begin{array}{l}\text { Nowak AJ, Christensen JR, Mabry } \\
\text { TR, Townsend JA, Wells MH } \\
\text { (2019), AAPD (2019) }\end{array}$ & Ibuprofen & $\begin{array}{l}20 \mathrm{mg} / \mathrm{kg} / \mathrm{day}[3] \\
\text { (maximum } 40 \mathrm{mg} / \mathrm{kg} / \\
\text { day) [8] }\end{array}$ & $\begin{array}{l}200 \mathrm{mg} \text { every } 4-6 \\
\text { hours [8] } \\
400-800 \mathrm{mg} / \text { day [2] }\end{array}$ & 1,2-2 g/day [2] \\
\hline $\begin{array}{l}\text { Jóźwiak-Bebenista M, Nowak JZ } \\
\text { (2014) }\end{array}$ & Acetaminophen & $\begin{array}{l}65 \mathrm{mg} / \mathrm{kg} / \mathrm{day}[2] \\
\text { (maximum } 75 \mathrm{mg} / \mathrm{kg} / \\
\text { day) [8] }\end{array}$ & $\begin{array}{l}325-650 \mathrm{mg} / \mathrm{day} \\
\text { [2] or } 1000 \mathrm{mg}, 3-4 \\
\text { times per day [8] }\end{array}$ & 4 g/day [8] \\
\hline
\end{tabular}

cations that may occur as a result of certain treatments. Out of a total of 100 dentists, $63 \%$ prescribed the medication according to the diagnosis and not the symptomatology itself, while clearly knowing the indications and contraindications of prescribing analgesics and anti-inflammatory drugs. However, all the subjects concluded that there is a need to create awareness programs for a better understanding of medication [12].

There is also a need for understanding the effects of delayed treatment with suboptimal doses of analgesics (table 3) [4].

Studies show that children who underwent dental extractions and those who experienced 12 or more dental interventions will undergo postoperative pain [14]. Unfortunately, when it comes to children, the assessment of pain is subjective. Because of that, various methods have been created that can help with the measurement of the intensity of pain in children, such as FACES pain scale and Wong-Baker FACES scale [8].

When we are doing the anamnesis, besides the severity of pain, it's very important to locate the pain, when it started, how it started, the pattern of the pain, the factors that intensify or ease it, the previous treatments and their effects [11].

Non-steroidal anti-inflammatory drugs are used for various pathologies, in different doses. Accord- ing to The National Institute of Health and Care Excellence (NICE), the treatment with non-steroidal anti-inflammatory drugs for children should be as short as possible, with the lowest possible dosage, in order to avoid and control the side effects $[7,15]$. To be able to use the lowest possible dosage of non-steroidal anti-inflammatory drugs, WHO recommends combining them with Paracetamol [14]. Therefore, Paracetamol can be used as a single treatment [11], or in combination with anti-inflammatory medication to treat a variety of pediatric conditions [7,14].

Due to the fact that it is very well tolerated by children, Ibuprofen is the only drug in the class of non-steroidal anti-inflammatories that has been approved to treat children under 3 years old [15]. It is also the most widely-used anti-inflammatory drug in paediatric dentistry [2]. Numerous studies have shown the efficacy of Ibuprofen in paediatric pathologies, as well as its high tolerance compared to other non-steroidal anti-inflammatory drugs [15].

In essence, both Ibuprofen and Paracetamol are considered to be equally safe and have a similar degree of tolerance in pediatric pathologies. Kanabar et al. showed in a meta-analysis of 19 studies that there were no significant differences between the two drugs in terms of the incidence of side effects in children [4].

TABLE 3. Indications, contraindications, form of presentation and side effects of Ibuprofen and Paracetamol in paediatric dentistry

\begin{tabular}{|l|l|l|l|}
\hline \multicolumn{1}{|c|}{ Author } & The Medicine & \multicolumn{1}{|c|}{ Indications } & \multicolumn{1}{c|}{ Contraindications } \\
\hline $\begin{array}{l}\text { Eccleston C, Cooper } \\
\text { TE, et al. (2017), } \\
\text { NICE (2012), Jóźwiak- } \\
\text { Bebenista M, Nowak JZ } \\
(2014)\end{array}$ & Ibuprofen & $\begin{array}{l}\text { mild and moderate pain, fever, after dental } \\
\text { extractions and dental surgical procedures [2] }\end{array}$ & $\begin{array}{l}\text { infants under three months old, } \\
\text { allergic disorders (hypersensitivity } \\
\text { to NSAIDs), ulcer, asthma, rhinitis, } \\
\text { nasal polyposis, uncontrolled heart } \\
\text { failure, kidney failure, liver failure, } \\
\text { oesophageal varicose veins, viral } \\
\text { infections (especially in newborns } \\
{[2,7,13,14]}\end{array}$ \\
\hline $\begin{array}{l}\text { Jóźwiak-Bebenista M, } \\
\text { Nowak JZ (2014) }\end{array}$ & Acetaminophen & $\begin{array}{l}\text { slight and moderate pain, fever, severe pain } \\
\text { caused by cancer, severe postoperative pain, } \\
\text { usually in combination with opioid analgesics, } \\
\text { when NSAIDs are contraindicated [2,13] }\end{array}$ & $\begin{array}{l}\text { liver dysfunctions [2] } \\
\end{array}$ \\
\hline
\end{tabular}




\section{SIDE EFFECTS}

Despite many benefits, there is documented evidence regarding the potential side effects, especially the gastrointestinal ones [6].

Non-steroidal anti-inflammatory drugs were originally created as an alternative to steroidal anti-inflammatory drugs and their numerous side effects. Nevertheless, the NSAIDs' action can affect the cardiovascular, respiratory and central nervous systems, causing adverse reactions such as headaches, tinnitus, irritability, hypertension, nausea, vomiting, hypersensitivity reactions (asthma, angioedema, rash). According to The World Health Organization (WHO), the most common side effects children's experience are: diarrhoea, tinnitus, nausea, headache, constipation, rash, flatulence, abdominal pain, dyspepsia $[7,14]$.

Approximately $25 \%$ of all adverse drug reactions are the consequences of treatments with anti-inflammatory drugs [9]. Local manifestations of toxicity in the gastrointestinal tract are represented by mucosal lesions, and systemically, by reducing the mucosa of prostaglandins derived from COX-1 [16]. Most commonly, side effects associated with non-steroidal anti-inflammatory drugs are located in the upper and lower gastrointestinal tract. In addition to lesions in the gastric mucosa, damage may also occur in the mucosa of the small intestine and colon [17]. Among the many complications that can occur are: gastric ulcer, bleeding and intestinal perforation $[5,15]$. Annually, there are over 100,000 people hospitalized in the United States, and between 7,000 and 10,000 deaths from these complications, most of those patients being in high-risk categories [6].

When it comes to antipyretics, in recent years, the concern about long-term side effects of Paracetamol increased, at first when it came to patients with hypertension, and later in patients with other conditions as well (table 4).
There is clear evidence of an increased risk of gastrointestinal bleeding and of a slight increase in systolic blood pressure (approximately $4 \mathrm{mmHg}$ ) in patients receiving acetaminophen. However, the risk of these side effects is dose dependent [10].

\section{SIDE EFFECTS IN CHILDREN}

Side effects rarely occur in children and there are limitations regarding the knowledge of the level of their manifestation. Most of the known data are based only on case reports and studies conducted in groups with a small number of patients [17]. In line with these observation, individual assessment remains the simplest tool to control and prevent unwanted side-effects.

A British study conducted for over 10 years illustrated the association of nonsteroidal anti-inflammatory drugs with the death of 12 children out of a total of 390 deaths $(0.03 \%)$. In 4 of these cases, aspirin is considered the causal factor, children (12-14 years) being diagnosed with Reye's syndrome. Another child who was given ibuprofen developed cerebral oedema, which could also could have been caused by Reye's syndrome. Another 4 children underwent gastrointestinal perforations, in 2 of the cases ibuprofens being considered the causal factor [18].

In another study that was observing children who suffer from rheumatoid arthritis and take a long-term treatment with non-steroidal antiinflammatory drugs, over $75 \%$ of patients experienced abdominal pain, gastritis or ulcer [17].

Grimaldi-Bensouda et al. report in a study that 83 of 177 children (46.9\%) with upper gastrointestinal bleeding have previously taken non-steroidal anti-inflammatory drugs at least once [19].

There is strong evidence that proves the link between non-steroidal anti-inflammatory drugs and gastrointestinal complications in adults, but much

TABLE 4. Side effects of Ibuprofen and Paracetamol in paediatric dentistry

\begin{tabular}{|l|l|l|}
\hline Author & Medicine & Side effects \\
\hline $\begin{array}{l}\text { Maghiar I(2011), Eccleston C, Cooper TE, } \\
\text { Fisher E, Anderson B, Wilkinson NMR (2017), } \\
\text { Matsui H, Shimokawa O, Kaneko T, Nagano Y, } \\
\text { Rai K, Hyodo I. (2011) }\end{array}$ & Ibuprofen & $\begin{array}{l}\text { Gastrointestinal effect (dyspepsia, nausea, constipation, vomiting, } \\
\text { abdominal pain, ulcer) headache, dizziness, drowsiness, pruritus, } \\
\text { oedema, hives, asthma attacks, renal impairment, hepatic function } \\
\text { impairment, cardiac impairment, coagulation defects [2,5,7,16] }\end{array}$ \\
\hline $\begin{array}{l}\text { Maghiar I (2011), McCrae JC, Morrison EE, } \\
\text { Maclntyre IM, Dear JW, Webb DJ (2018). }\end{array}$ & Acetaminophen & $\begin{array}{l}\text { Gastrointestinal bleeding, increase of systolic blood pressure, } \\
\text { liver damage, skin reactions: Steven-Johnson syndrome, toxic } \\
\text { epidermal necrolysis, asthma attacks, renal insufficiency [2,5,10] }\end{array}$ \\
\hline
\end{tabular}


more is needed in pediatric patients [17]. Bianciotto et al. reported, on behalf of the Italian Multicentre Study Group for Drug and Vaccine Safety in Children, an increased risk of gastrointestinal bleeding after treatment with various drugs, including non-steroidal anti-inflammatory drugs, corticosteroids and antibiotics [20].

Overall, despite the widespread use of ibuprofen and paracetamol, thankfully the rate of severe side effects in children is low. Both drugs are associated with rare specific side effects, which are generally difficult to detect in small studies; these are easier to quantify in larger research groups [4].

\section{REFERENCES}

1. Yatoo MI, Gopalakrishnan A, Saxena A, Parray OR, Tufani NA, Chakraborty S, Tiwari R, Dhama K, Iqbal HMN. Anti-Inflammatory Drugs and Herbs with Special Emphasis on Herbal Medicines for Countering Inflammatory Diseases and Disorders - A Review. Recent Pat Inflamm Allergy Drug Discov. 2018;12(1):39-58.

2. Mesaros M, Muntean A, Medicină dentară pediatrică. Cluj-Napoca: Editura Medicală Universitară "Iuliu Haţieganu", 2016.

3. Nowak AJ, Christensen JR, Mabry TR, Townsend JA, Wells MH (editors). Pediatric Dentistry: Infancy through adolescence. $6^{\text {th }}$ ed. Elsevier. 2019.

4. Kanabar KJ. A clinical and safety review of paracetamol and ibuprofen in children. Inflammopharmacology. 2017 Feb;25(1):1-9.

5. Maghiar I. Farmacologie. Elemente de farmacologie fundamentală, farmacologie clinică si toxicologie clinică. Editia a 3a, revizuită. Editura Universităţii din Oradea. 2011.

6. Cardile S, Martinelli M, Barabino A, Gandullia P, Oliva S, Di Nardo $\mathrm{G}$, et al. Italian survey on non-steroidal anti-inflammatory drugs and gastrointestinal bleeding in children. World J Gastroenterol. 2016 February 7;22(5):1877-1883.

7. Eccleston C, Cooper TE, Fisher E, Anderson B, Wilkinson NM. Non-steroidal anti-inflammatory drugs (NSAIDs) for chronic non-cancer pain in children and adolescents. Cochrane Database Syst Rev. 2017 Aug 2;8(8):CD012537.

8. American Academy of Pediatric Dentistry. Useful Medications for Oral Conditions, The reference manual of pediatric dentistry, American Academy of Pediatric Dentistry. 2019.

9. Singh G. Gastrointestinal complications of prescription and over-the-counter nonsteroidal anti-inflammatory drugs: a view from the ARAMIS database. Arthritis, Rheumatism, and Aging Medical Information System. Am J Ther. 2000 Mar;7:115-121.

10. McCrae JC, Morrison EE, MacIntyre IM, Dear JW, Webb DJ. Long-term adverse effects of paracetamol - a review. $\mathrm{Br} J$ Clin Pharmacol. 2018. Oct; 84(10):2218-2230.

11. Chou R, Gordon DB, de Leon-Casasola OA, et al. Management of Postoperative Pain: A Clinical Practice Guideline from the American Pain Society, the American Society of Regional Anesthesia and Pain Medicine, and the American Society of Anesthesiologists' Committee

\section{CONCLUSIONS}

More than 30 million people are using prescribed non-steroidal anti-inflammatory drugs daily. Ibuprofen is considered by the World Health Organisation to be the only safe enough anti-inflammatory to be prescribed to children under 3 years old. However, in the case of short-term treatments (less than 7 days), such as those in pedodontics and dentistry in general, both ibuprofen and paracetamol are considered safe and with a similar tolerance. The continuous education and awareness programs are necessary, for both doctors and general population.

\section{Conflict of interest: none declared Financial support: none declared}

on Regional Anesthesia, Executive Committee, and Administrative Council. J Pain. 2016 Feb;17(2):131-57.

12. Monisha M, Elengickal TJ, Ram SK, Madhu M, Raghuveeran M. Attitude and Awarness of Dentists Practicing in South India Toward Non-Steroidal Antiinflamatory Drugs. J Pharm Bioallied Sch. 2019 May:11(Suppl 2):S355-S359.

13. Jóźwiak-Bebenista M, Nowak JZ. Paracetamol: mechanism of action, applications and safety concern. Acta Pol Pharm. 2014 Jan-Feb;71(1):11-23.

14. National Institute of Health and Care Excellence (NICE). Sickle cell acute painful episode. 2012. Available at: https://www.nice.org.uk/ guidance/cg143.

15. De Martino M, Chiarugi A, Boner A, Montini G, De' Angelis GL editors. Working Towards an Appropriate Use of Ibuprofen in Children: An Evidence-Based Appraisal. Drugs. 2017 Aug;77(12):1295-1311.

16. Matsui $\mathrm{H}$, Shimokawa O, Kaneko T, Nagano Y, Rai K, Hyodo I. The pathophysiology of non-steroidal anti-inflammatory drug (NSAID)induced mucosal injuries in stomach and small intestine. J Clin Biochem Nutr. 2011 Mar;48(2):107-111.

17. Etienney I, Beaugerie L, Viboud C, Flahault A. Non-steroidal anti-inflammatory drugs as a risk factor for acute diarrhoea: a case crossover study. Gut. 2003 Feb;52(2):260-3.

18. Clarkson A, Choonara I. Surveillance for fatal suspected adverse drug reactions in the UK. Arch Dis Child. 2002 Dec;87(6):462-6.

19. Grimaldi-Bensouda L, Abenhaim L, Michaud L, Mouterde O, Jonville-Béra AP, Giraudeau B, David B, Autret-Leca E. Clinical features and risk factors for upper gastrointestinal bleeding in children: a case-crossover study. Eur J Clin Pharmacol. 2010 Aug;66(8):831-837.

20. Bianciotto M, Chiappini E, Raffaldi I, Gabiano C, Tovo PA, Sollai S, de Martino M, et al.; Italian Multicenter Study Group for Drug and Vaccine Safety in Children. Italian Multicenter Study Group for Drug and Vaccine Safety in. Drug use and upper gastrointestinal complications in children: a case-control study. Arch Dis Child. 2013;98:218-221. 